\title{
Vaginal Secretion Epithelium Count as a Prognostic Indicator of High Abundance of Ureaplasmas in Women with a Normal Nugent Score
}

\author{
MAŁGORZATA BIERNAT-SUDOLSKA ${ }^{1}{ }^{\oplus}$, KATARZYNA TALAGA-ĆWIERTNIA $^{1 \star}{ }^{\circledR}$ and PAULINA GAJDA ${ }^{2}{ }^{\circledR}$ \\ ${ }^{1}$ Jagiellonian University Medical College, Faculty of Medicine, Chair of Microbiology, \\ Department of Molecular Medical Microbiology, Cracow, Poland \\ ${ }^{2}$ Jagiellonian University Medical College, Faculty of Medicine, Chair of Epidemiology and Preventive Medicine, \\ Department of Epidemiology, Cracow, Poland
}

Submitted 1 July 2021, accepted 7 December 2021, published online 27 February 2022

\begin{abstract}
Genital tract ureaplasma infections are associated with numerous complications, ranging from inflammation, through infertility, to problematic pregnancy. In the course of ureaplasma infection, the risk of human papillomavirus infection increases. Diagnostic tests for ureaplasma infections are not always carried out, especially in women with the normal Nugent test results. The study attempts to check whether it is possible to find a prognostic indicator that could suggest a high abundance of ureaplasmas $\left(\geq 10^{4} \mathrm{CFU} / \mathrm{ml}\right)$ at the stage of the initial examination of vaginal discharge. Such a prognostic factor could qualify women for further tests to detect infections with these atypical bacteria. Six hundred twenty-seven white women with a score of $0-3$ on the Nugent scale were tested, including 322 patients with a high abundance of ureaplasmas $\left(\geq 10^{4} \mathrm{CFU} / \mathrm{ml}\right)$ and 305 who tested negative for these bacteria. Ureaplasma infections were detected statistically significant in women who had few or no epithelial cells in the genital swab specimens compared to the results obtained for women with numerous or very numerous epithelial cells $(p<0.001)$. The risk of the high density of ureaplasmas was $38.7 \%$ higher with fewer or no epithelial cells than with high numbers. In patients aged 18-40 years with few or no epithelial cells, a high density of ureaplasmas $\left(\geq 10^{4} \mathrm{CFU} / \mathrm{ml}\right)$ was observed significantly more frequently $(p=0.003)$. Determining the number of epithelial cells in Gram-stained slides may be the prognostic indicator of ureaplasma infection. Testing for genital ureaplasma infection should be considered, especially in women of childbearing age (18-40 years), even if the Nugent test value is normal and $\mathrm{pH} \leq 4.6$.
\end{abstract}

Ke y w o rds: Ureaplasma, epithelial cells, Nugent scale, Lactobacillus, leukocytes, pH

\section{Introduction}

The primary method for studying the microorganisms of the lower genital tract in women is the Nugent method. It was considered the gold standard worldwide due to its low cost and ease of implementation (Schwebke et al. 1996). It was a routine test performed for every woman in Poland to initially assess the possible etiological factors of the observed genital tract symptoms. This method is based on the evaluation of Gram-stained preparations, so it only shows typical bacteria classified as Gram-positive or Gram-negative (Nugent et al. 1991). In its current form, the Nugent method does not show the presence of atypical bacteria lacking a cell wall, such as ureaplasmas. Ureaplas- mas belong to the family Mycoplasmataceae and are the smallest and the simplest self-reproducing bacteria (Razin 1992). They are most commonly sexually transmitted and have been detected in both healthy and symptomatic people. These bacteria are believed to have low virulence and are part of the normal vaginal microbiota. Their pathogenicity has not been confirmed, and the research results on this problem are inconclusive. However, it is believed that their excessive multiplication $\left(\geq 10^{4} \mathrm{CFU} / \mathrm{ml}\right.$ - considered an infection) may cause complications. Most often, ureaplasma infections are assigned a role in NGU (non-gonococcal urethritis) and male infertility (negative influence on sperm metabolism, mobility, and penetration into the ovum) (TaylorRobinson 1986; Núñez-Calonge et al. 1998). Ascending

\footnotetext{
* Corresponding author: K. Talaga-Ćwiertnia, Jagiellonian University Medical College, Faculty of Medicine, Chair of Microbiology, Department of Molecular Medical Microbiology, Cracow, Poland; e-mail: katarzyna.talaga@uj.edu.pl

(c) 2022 Małgorzata Biernat-Sudolska et al.

This work is licensed under the Creative Commons Attribution-NonCommercial-NoDerivatives 4.0 License (https://creativecommons. org/licenses/by-nc-nd/4.0/).
} 
infection with urinary tract ureaplasma may lead to cystitis and glomerulonephritis and nephritis with plaque deposition (McDonald et al. 1982; Dewan et al. 1997). Infection of the cervix may result in premature birth (Kundsin et al. 1996) and infections in neonates in whom respiratory symptoms are mainly observed. There are suggestions that chronic ureaplasma-induced cervicitis could damage the mucosal barrier and immune protection (Lv et al. 2019). Ureaplasmas causing inflammation of the cervix increase the production of free radicals, which damages the cervical epithelial barrier and reduces the immune clearance facilitating the penetration of other pathogens (Brylk et al. 2020).

The aim of the study was to find potential prognostic factors indicating high number of ureaplasmas in women without clinical symptoms and with normal Nugent score. The analysis included indicators such as the number of epithelial cells, leukocytes, and lactobacilli, as well as $\mathrm{pH}$ measurement, which can be simultaneously assessed using the criteria of the Nugent method as it has an established place in the diagnosis of female genital dysfunction (Nugent et al. 1991; Taj et al. 2014). Such preliminary assessment could qualify patients for further research, including more expensive molecular diagnostics.

\section{Experimental}

\section{Materials and Methods}

Our analysis (No. KBET/1072.6120.191.2020; approved by the Bioethics Committee of the Jagiellonian University) had a retrospective character and covered 627 women who were examined in 2007-2014.

The authors decided not to use the term 'ureaplasma infection' in this study because the patients included in the analysis did not show clinical symptoms.

Cervical and vaginal swabs were taken from each woman using sterile polystyrene shafts with viscose swabs and placed in sterile transport tubes without a medium (Deltalab, Poland). Material from the genital tract was not collected during menstrual bleeding, from women undergoing antibiotic therapy, or within two weeks after the antibiotic therapy. Vaginal swabs were seeded for Trichonema vaginalis, yeast-like fungi of the genus Candida, Neisseria, streptococci, enterococci, Enterobacterales, and Gardnerella vaginalis. Only women with a high number of ureaplasmas $\left(\geq 10^{4} \mathrm{CFU} / \mathrm{ml}\right)$ were included. We excluded women with mycoplasma-ureaplasma co-infections and ureaplasma with all of the above. The presence of $T$. vaginalis was confirmed from direct preparations of the collected vaginal discharge. Aerobic bacteria were cultured on Columbia Agar with 5\% sheep blood (Biocorp) incubated in aerobic conditions at $37^{\circ} \mathrm{C}$ for 24 hours. The same conditions were applied to Enterobacterales cultured on MacConkey agar (Biocorp) and enterococci cultured on Bile Esculin Azide LAB-agar (Biocorp). The presence of G. vaginalis was confirmed by the BD Gardnerella Selective Agar with 5\% Human Blood (BD), whereas MRS Agar (Oxoid) was used for lactobacilli. Neisseria gonorrhoeae was detected on the Roiron agar incubated in $5 \% \mathrm{CO}_{2}$ atmospheric conditions for 24-48 hours. Schaedler medium (BD) with vitamin K and $5 \%$ sheep blood was used for strictly anaerobic bacteria. Anaerobic bacteria were cultured under strictly anaerobic conditions at $37^{\circ} \mathrm{C}$ for 48 hours. Clinical materials were incubated on Sabouraud agar (Biocorp) under aerobic conditions at $37^{\circ} \mathrm{C}$ for 24 hours to detect the genus Candida yeast-like fungi.

Specimens collected from the cervix wall were examined for the presence of atypical bacteria (Mycoplasma hominis, Ureaplasma spp., and Chlamydia trachomatis). The presence of C. trachomatis was confirmed by demonstrating intracytoplasmic inclusions in the bacteria grown in McCoy cells. Intracytoplasmic inclusions were detected after 48 hours by iodine staining. A Mycoplasma IST 2 kit was used for detection of mycoplasma and ureaplasma infections (BioMérieux). This test allows identification of genital mycoplasma within 48 hours and quantitative estimation of the number of bacteria $\left(\geq 10^{4} \mathrm{CFU} / \mathrm{ml}\right)$. The cervical secretions were transferred to the BioMérieux transport medium, which was then transferred to BioMérieux culture media, and liquid and solid PPLO medium according to the procedures described earlier by Hayflick (Hayflick 1965; Biernat-Sudolska et al. 2006).

The collected vaginal discharge allowed to concurrently prepare a smear on a slide and stain it with the Gram method for the Nugent method (Nugent et al. 1991). Then, the smears were evaluated by the Nugent scoring system and assigned scores of $0-10$. The Nugent score for bacterial vaginosis (BV) is based on the total number of large Gram-positive rods (Lactobacillus morphotypes), the number of small Gram-variable and Gram-negative rods (G. vaginalis, Bacteroides, and Prevotella morphotypes), and curved Gram-negative rods (Mobiluncus morphotypes). Each morphotype was quantified per field, and a summed score was given. A score of $0-3$ is representative of a normal microbiota, a score of 4-6 coresponds to disturbed or altered microbiota, and a score of $7-10$ is consistent with BV microbiota. The Nugent score was evaluated by only one experienced microbiologist to prevent the interobserver variation, using a magnification of $1,000 \times$ (an oil immersion). Two categories were adopted when assessing the number of leukocytes and epithelial cells: I - no/few (0-2), and II - numerous/very numerous $(3 \geq 4)$ per slide field. When assessing the number of Lactobacillus morphotypes, the categories as presented 
Table I

Control and study group patient characteristics considering patient age and $\mathrm{pH}$ value.

\begin{tabular}{|l|c|c|c|c|c|c|c|c|c|c|c|c|}
\hline & \multicolumn{4}{|c|}{ Control group $\mathrm{n}=305$} & \multicolumn{4}{c|}{ Study group $\mathrm{n}=322$} \\
\cline { 2 - 38 } & Med & IQR & M & SD & Min & Max & Med & IQR & M & SD & Min & Max \\
\hline Age & 30.0 & $(27.0 ; 34.0)$ & 30.8 & 6.1 & 18.0 & 63.0 & 31.0 & $(26.0 ; 35.0)$ & 31.4 & 6.5 & 19.0 & 56.0 \\
\hline $\mathrm{pH}$ & 4.6 & $(4.6 ; 4.9)$ & 4.7 & 0.3 & 3.8 & 5.5 & 4.6 & $(4.6 ; 4.9)$ & 4.7 & 0.3 & 4.0 \\
\hline
\end{tabular}

Med - median, M - mean, SD - standard deviation, IQR - interquartile range, Min - minimum, Max - maximum

previously in the Nugent scoring were adopted, and there were: I - no(0), II - few (1-5), III - numerous (6-30), IV - very numerous ( $>30)$ per field.

The $\mathrm{pH}$ of the vaginal discharge was assessed immediately after collection. It was measured with the PEHANON colored indicator strips (Macherey-Nagel $\mathrm{GmbH} \&$ Co. KG) and ranged from 3.8 to 5.5. The values of $\leq 4.6$ were considered correct.

The analysis covered adult white women who visited the Microbiological Diagnostics Laboratory of the Department of Microbiology of the Jagiellonian University Medical College. The women came for a prophylactic examination of the vaginal microbiota before a planned pregnancy (without subjective symptoms of infection in the genital tract) or due to symptoms such as vaginal discharge, irritation, and itching.

Specimens with a score of $0-3$ on the Nugent scale were selected for our analysis. The control group $(\mathrm{n}=305)$ included women who did not demonstrate the presence of infection with ureaplasma. The study group $(n=322)$ included women with the high number of ureaplasmas $\left(\geq 10^{4} \mathrm{CFU} / \mathrm{ml}\right)$. In both the control group and the study group to determine the influence of age on the assessed prognostic indicators, the subjects were divided into four age groups: I: $18-30$ years; II: 31-40; III: 41-50; IV: over 50. In the study group, the number of patients in the 1st group was $n=160$; II: $n=137 ;$ III: $n=20 ;$ IV: $n=5$, and in the control group, respectively, I: $n=173$; II: $n=110$; III: $n=20$; IV: $n=2$.

Control and study group patient characteristics are presented in Table I. The age and $\mathrm{pH}$ values were expressed as the median and interquartile range (IQR). Intergroup differences were analyzed using Fisher's exact and Pearson's chi-square test. A one-way logistic regression model was used to estimate the risk of the high density of ureaplasmas ( $\left.\geq 10^{4} \mathrm{CFU} / \mathrm{ml}\right)$. Statistical analysis was performed using IBM SPSS Statistics 26. The significance level for all statistical tests was set at $p<0.05$.

\section{Results}

To determine the risk of high abundance of ureaplasmas $\left(\geq 10^{4} \mathrm{CFU} / \mathrm{ml}\right)$ based on the presence of the prognostic indicators studied by us, we conducted analyses covering both a single indicator and several indicators in various combinations with one another.

The high density of ureaplasmas versus the $\mathbf{p H}$ value. A high number of ureaplasmas $\left(\geq 10^{4} \mathrm{CFU} / \mathrm{ml}\right)$ were observed in $53.6 \%$ of women with $\mathrm{pH} \leq 4.6$ and in $48.6 \%$ of women with $\mathrm{pH}>4.6$. These differences were not statistically significant $(p=0.242$, Pearson's chi-square test).

The high abundance of ureaplasmas and the number of bacteria of the genus Lactobacillus. A high number of ureaplasmas $\left(\geq 10^{4} \mathrm{CFU} / \mathrm{ml}\right)$ occurred in $52 \%$ of women in whom Lactobacillus bacteria were numerous and very numerous. In contrast, those infections were found in $44 \%$ of women with few or any bacteria. These differences were not statistically significant ( $p=0.349$; Pearson's chi-square test).

The high density of ureaplasmas and the number of epithelial cells. In our studies, the high number of ureaplasmas $\left(\geq 10^{4} \mathrm{CFU} / \mathrm{ml}\right)$ was confirmed more often in women who had few or no epithelial cells in the specimens from the genital swabs. Compared to the results obtained for women with numerous or very numerous epithelial cells, these results were statistically significant ( $58.1 \%$ vs. $36.4 \%, p<0.001$, Pearson's chi-square test).

Using a one-way logistic regression model, it was shown that in women with the Nugent score 0-3 $(n=627)$, the risk of a high abundance of ureaplasmas $\left(\geq 10^{4} \mathrm{CFU} / \mathrm{ml}\right.$ ) is $38.7 \%$ higher with few / no epithelial cells than with numerous/very numerous epithelial cells (OR 1.38, CI 1.14-1.68, $p=0.001$ ).

The high density of ureaplasmas versus the presence and number of leukocytes. In our study, the high number of ureaplasmas $\left(\geq 10^{4} \mathrm{CFU} / \mathrm{ml}\right)$ were observed in $52.8 \%$ of patients with low or no leukocytes in the vaginal smear and in $44.0 \%$ of women with numerous or very numerous leukocytes. There were no statistically significant differences between these groups ( $p=0.135$, Pearson's chi-square test). The comparison of the control group and the study group, taking into account individual prognostic indicators, is shown in Fig. 1.

Incidence of high abundance of ureaplasmas versus different combinations of prognostic indicators. The statistically significant results were obtained only in three cases when assessing the frequency of the high 
A

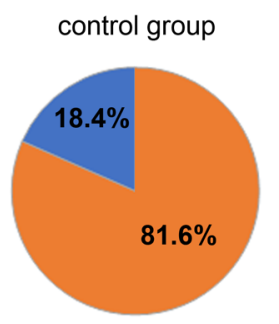

B

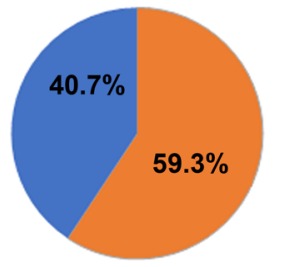

C

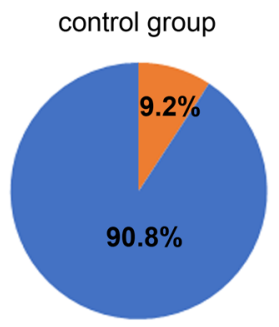

D

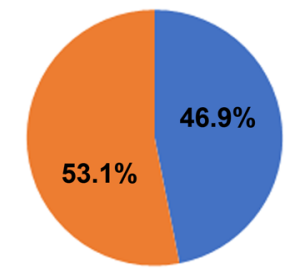

study group
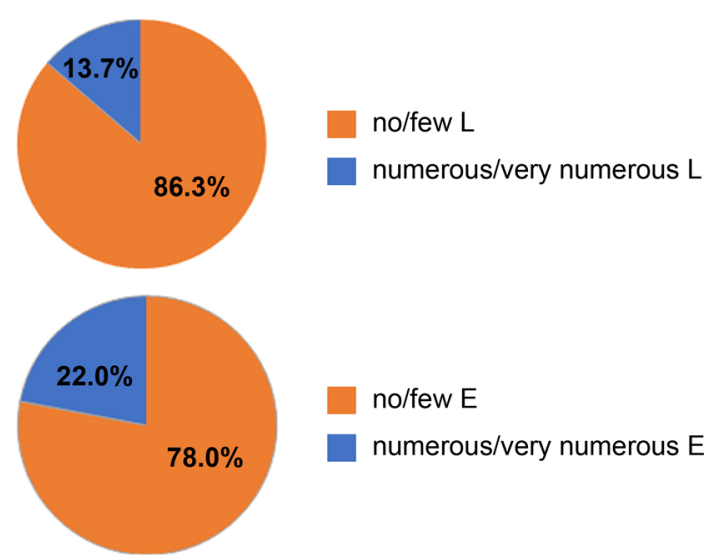

study group

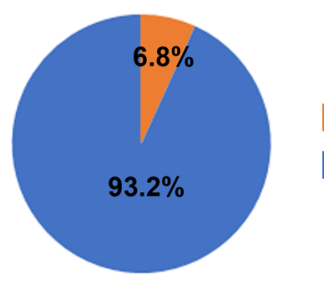

no/few Lactobacillus

numerous/very numerous Lactobacillus

Fig. 1. Comparison between the control group and the study group, taking into account individual diagnostic indicator tested in the study: A) leukocytes - L, B) epithelial cells - E

number of ureaplasmas $\left(\geq 10^{4} \mathrm{CFU} / \mathrm{ml}\right)$, with various combinations of the analyzed indicators. Our analysis showed that high density of these atypical bacteria occurs significantly more often when i) leukocytes and epithelia were few or absent ( $57.8 \%$ vs. $32.2 \%, p<0.001$, Pearson's chi-square test); ii) in the presence of few/ no epithelia and $\mathrm{pH} \leq 4.6$ (60.6\% vs. $39.0 \%, p<0.001$, Pearson's chi-square test); iii) when there were no leukocytes and epithelial cells, or there were few of these cells, and the $\mathrm{pH}$ value was below 4.6 (60.6\% vs. $39.5 \%, p=0.022$, Pearson's chi-square test). A comparison of the percentage of women in the control and study groups, taking into account the combined prognostic indicators for which statistical significance was determined, is presented in Fig. 2. Using a oneway logistic regression model, it was shown that the risk of high abundance of ureaplasmas $\left(\geq 10^{4} \mathrm{CFU} / \mathrm{ml}\right)$ is $37.0 \%$ higher in the case when, simultaneously, leukocytes and epithelia were almost absent or absent $(\mathrm{n}=450$; OR 1.37, CI 1.12-1.67, $p=0.002)$. Our analysis also showed that the risk of the high number of ureaplasmas is $53.9 \%$ higher in women with a $\mathrm{pH}$ value below 4.6 who have few or no epithelial cells $(n=364$
OR 1.54, CI 1.20-1.97, $p=0.001)$. With the simultaneous presence of three indicators: scarce or absent leukocytes and epithelial cells and a $\mathrm{pH} \leq 4.6$, the risk of the high density of ureaplasmas $\left(\geq 10^{4} \mathrm{CFU} / \mathrm{ml}\right)$ is $54.1 \%$ higher $(\mathrm{n}=287$; OR 1.54, CI 1.19-1.98, $p=0.001)$, compared to when the $\mathrm{pH}$ value is above 4.6 , and the epithelial cells and leukocytes are abundant.

Incidence of the high density of ureaplasmas versus age. In the age groups I and II, the high number of ureaplasmas were significantly more frequent in patients with few or no epithelial cells (respectively, $55.5 \%$ vs. $33.6 \%, p<0.001$ and $61.6 \%$ vs. $40.0 \%$, $p=0.003$, Pearson's chi-square test). In the case of other indicators, analyzed separately or in various combinations, no statistically significant differences were found in individual age groups.

The age-standardized logistic regression model showed that the risk of the high density of ureaplasmas was $121.3 \%$ higher (OR 2.21, CI 1.58-3.10, $p<0.001$ ) in the presence of only a few or absence of epithelial cells. The risk of high abundance of ureaplasmas decreases with the patient's age, by $1.5 \%$ with each subsequent year (OR 0.98, CI 0.97-0.99, $p=0.001$ ). 


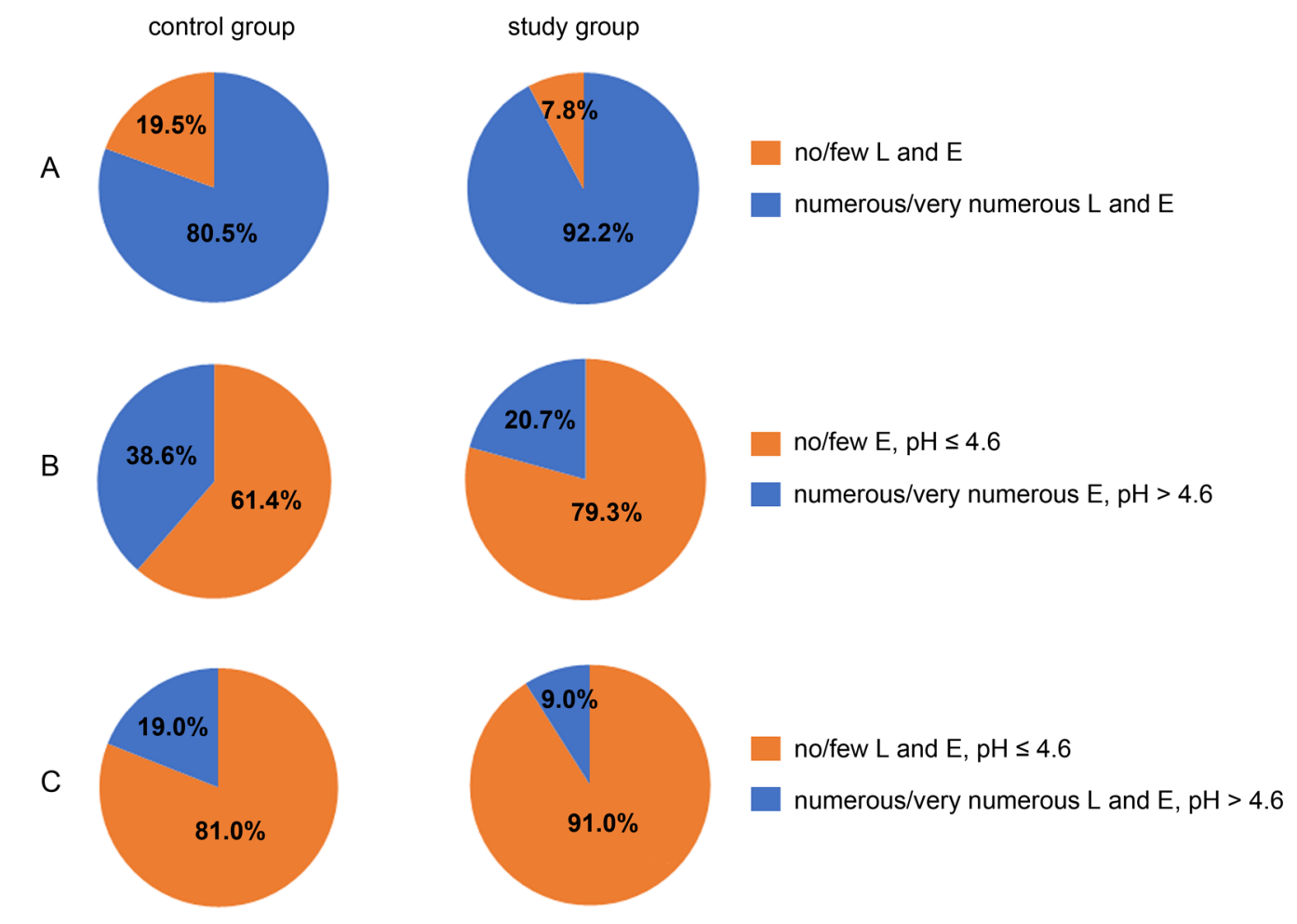

Fig. 2. Comparison of the control and study groups, taking into account the combination of the diagnostic indicators tested: A) leukocytes - L and epithelial cells $-\mathrm{E}, p<0.001$; B) epithelial

\section{Discussion}

Our many years of experience in the diagnosis of genital tract infections were the starting point for the initial assessment of the dependence of ureaplasma infections on the results of the Nugent scale. The results not presented in this study showed that ureaplasma infections were significantly more common in women with a score of $0-3$ on the Nugent scale $(n=768$, $p<0.001$, Pearson's chi-square test). Our observations suggested that the results obtained with this method do not correlate with the high density of ureaplasmas. Therefore, our present research attempted to find prognostic indicators assessed in parallel with the commonly used Nugent method, which could indirectly indicate infection with these bacteria. The indicators selected for our analysis included the number of Lactobacillus, the number of epithelia and leukocytes, and the $\mathrm{pH}$ value in determining the risk of ureaplasma infection. Epithelial cells and leukocytes are visible on microbiological slides after Gram staining but are not assessed in the Nugent method. The diagnostic value of leukocytes as a prognostic indicator indirectly suggestive of ureaplasma infection was demonstrated by Okodo et al. (2017). These researchers, analyzing preparations made with the Papanicolaou technique, showed a statistically significant relationship between the Ureaplasma urealyticum infection and the presence of secondary changes in the cells of the cervical squamous epithelium called cannonballs. Out of the morphotypes assessed by the Nugent method, we chose the number of Lactobacillus, noting the considerable impact of this type of bacteria on the vaginal microbiota, which is clearly emphasized in the literature (Tachedjian et al. 2017; Witkin and Linhares 2017).

It has long been known that numerous antibacterial agents produced by lactobacilli, including bacteriocins, $\mathrm{H}_{2} \mathrm{O}_{2}$, or lactic acid, can inhibit the excessive multiplication of various pathogens. In our study, however, no dependence of the high number of ureaplasmas on the number of lactobacilli was observed. Some Lactobacillus species, regardless of their abundance, may be more active than others in keeping Ureaplasma spp. below the level considered being an infection. This, however, requires further research (Daniele et al. 2011).

Lactic acid, produced by Lactobacillus, plays a unique role in the vagina, favoring the domination of microorganisms with low pathogenic potential. Some Lactobacillus species produce only the D-isomer of lactic acid, which has a weaker protective effect (Amabebe and Anumba 2018). For example, Lactobacillus iners that dominate the vaginal microbiota is usually associated with dysbiosis. It appears to be less stable and more susceptible to alteration (since this species does not produce lactic acid). Similarly, Lactobacillus jensenii has weaker protective properties (it only produces D-lactic acid). On the other hand, Lactobacillus crispatus is beneficial as this species produces both $\mathrm{D}$ - and 
L-lactic acid, associated with increased stability of the vaginal microbiota (developing dysbiosis is less probable), thus producing lower risk of BV. Perhaps routine determination of the number and species of Lactobacillus would be beneficial as it could indicate the risk of BV (Virtanen et al. 2019) and the possibility of various infections, including genital mycoplasmas.

Another indicator selected here was the number of epithelia. It is known that ureaplasmas strongly adhere to various cells, including epithelial cells (Razin 1992; 1999). G. vaginalis is a microorganism with strong adhesive properties. Its adherence to the epithelium is observed in Gram-stained preparations as characteristics indicator cells. To clearly assess the impact of high number of ureaplasmas $\left(\geq 10^{4} \mathrm{CFU} / \mathrm{ml}\right)$ on vaginal epithelial cells, the analysis did not include women infected with G. vaginalis. By adhering to the epithelium, ureaplasmas can damage the cells, and the irritating ammonia produced by them can influence the development of the inflammation. We expected that such actions could affect the number of exfoliated epithelial cells and leukocytes found in Gram-stained slides. The abundance of these cells could be a possible marker of an ongoing ureaplasma infection. In our analysis, a higher incidence of ureaplasma infections was observed only in the absence or with low numbers of epithelia. This relationship is also visible when the $\mathrm{pH}$ value is within the normal range. The beneficial effects of lactic acid on the cervix and vaginal epithelial cells (increased survival of vaginal epithelial cells, facilitated repair of damaged DNA) were demonstrated (Wagner et al. 2015; Amabebe and Anumba 2019). As a result, vaginal epithelial cells protected with lactic acid probably peel to a lesser extent, hence perhaps in Gramstained preparations, their small number was observed with a large number of Lactobacillus bacteria.

Our analysis showed no dependence of high density of ureaplasmas $\left(\geq 10^{4} \mathrm{CFU} / \mathrm{ml}\right)$ on the number of leukocytes. Our observations regarding the number of leukocytes are in line with the previous literature reports. Lactic acid produced by lactobacilli supports antimicrobial defense through multiple mechanisms without causing immune-mediated inflammation. The vaginal microbiome dominated by L.crispatus, L. gasseri, and L. jensenii is potentially associated with a lower pro-inflammatory response (Smith and Ravel 2017; Witkin and Linhares 2017). This anti-inflammatory effect was previously observed in the presence of a large number of lactobacilli, especially at low $\mathrm{pH}$, which enhances lactic acid activity (Hearps et al. 2017; Tachedjia et al. 2017; Amabebe and Anumba 2018). In a study of urinary tract infections, Moi et al. (2017) observed a weaker inflammatory response with ureaplasma than C. trachomatis and M. genitalium. Other researchers, such as Geisler et al. (2003), indicated that assessing the number of leukocytes in vaginal and cervical infections has a low positive and negative predictive value and moderate sensitivity and specificity. We also included $\mathrm{pH}$ measurements in our analysis, as it is known from the literature that the low $\mathrm{pH}$ of the vaginal discharge is most often associated with normal vaginal microbiota. Nevertheless, reports indicate that vaginal acidity may be more critical for the proper functioning of the vaginal mucosa than for inhibiting potential pathogens or regulating the normal microbiota. Measuring the $\mathrm{pH}$ alone in the screening of vaginal microbiota seems insufficient as it is known that Candida infections can occur at low $\mathrm{pH}$ values (Linhares et al. 2011). Different species of Lactobacillus lower the $\mathrm{pH}$ of the vaginal discharge to a varying extent, and in women with a score of $0-3$ on the Nugent scale, a differentiation in $\mathrm{pH}$ was found, with an upward trend closer to the limit of the range (O'Hanlon et al. 2019). The products of ureaplasma metabolism alkalize the environment, which may neutralize the acidity resulting from the presence of Lactobacillus. With a huge population of Lactobacillus spp., the acidity of vaginal secretions is not always disturbed. There is no apparent shift of the measurement results towards alkaline values. As a result, this may have resulted in the $\mathrm{pH}$ values being within the normal range despite the ureaplasma infection. In our research, only the $\mathrm{pH}$ value combined with the determination of the number of epithelia and leukocytes gained a significant diagnostic significance.

The results obtained here turned out to be statistically significant in women of reproductive age, who are usually the most sexually active. Due to the prospect of motherhood, women from this group most often report for vaginal microbiota tests. Therefore, the assessment of epithelial cells would be particularly important for this group of women due to the consequences of ureaplasma vertical infection in their children. It would also be valuable due to the relationship between ureaplasma $\left(\geq 10^{4} / \mathrm{ml}\right)$ and possible damage to the epithelium in the genital system, which creates good conditions for the penetration of other sexually transmitted pathogens which have a negative impact on women health (Lv et al. 2019; Ye et al. 2018).

In our study, statistically significant results were obtained when the number of epithelia was analyzed as a single prognostic indicator as well as together with other analyzed indicators. Therefore, it seems to us that vaginal secretion epithelial cell count has the greatest importance and can be considered a prognostic indicator of the presence of high density of ureaplasmas.

The use of molecular methods that are currently widely available might have some impact on the results presented. However, in the years 2007-2014 in which the studies covered by our analysis were performed, the methods of bacterial cultivation on microbiological 
media were routinely used in Poland. In those years, culture methods were considered the gold standard in microbiological diagnostics and, in many countries, they have been the most important until now. Our study only involved women from the white ethnic group, which of course, limits the possibility of extending the conclusions to the entire female population. A weakness of our work, resulting from its retrospective nature, was also the lack of data that could be obtained from the patients included in the analysis, concerning e.g., hygienic behavior, number of sexual partners, the possibility of using lubricants, hormonal contraception, or the day of the menstrual cycle on which the vaginal discharge was collected. Such data could have influenced the results of our analysis.

\section{Conclusions}

Our analysis showed that even the introduction of additional prognostic indicators expanding the Nugent scale did not allow the presence of the high number of ureaplasmas to be clearly demonstrated. The relatively best prognostic indicator of the ongoing high density of ureaplasmas $\left(\geq 10^{4} \mathrm{CFU} / \mathrm{ml}\right)$ in women with normal Nugent scores was the determination of the number of epithelial cells. Our analysis also shows that testing for genital ureaplasma should be considered, especially in women of childbearing age (18-40 years), even if the Nugent test value is normal and the $\mathrm{pH}$ is $\leq 4.6$.

\section{(1) ORCID}

Małgorzata Biernat-Sudolska https://orcid.org/0000-0002-5943-6007 Katarzyna Talaga-Ćwiertnia https://orcid.org/0000-0003-0811-9295 Paulina Gajda https://orcid.org/0000-0001-7687-7536

\section{Ethical statement}

This study was approved by the Bioethics Committee of the Jagiellonian University (No. KBET/1072.6120.191.2020).

\section{Acknowledgments}

The authors would like to thank prof. Małgorzata Bulanda for providing the database.

\section{Author contributions}

Conceptualization, M. B-S.; Methodology, M. B-S. and K. T-Ć.; Formal Analysis, M. B-S., K. T-Ć. and P.G.; Investigation, P.G.; Resources, M. B-S.; Data Curation, M. B-S.; Writing - Original Draft Preparation, M. B-S. and K. T-Ć.; Writing - Review \& Editing, M. B-S. and K. T-Ć.; Visualization, M. B-S. and K. T-Ć.; Supervision, M. B-S. and K. T-Ć.; Project Administration, K. T-Ć.

\section{Conflict of interest}

The authors do not report any financial or personal connections with other persons or organizations, which might negatively affect the contents of this publication and/or claim authorship rights to this publication.

\section{Literature}

Amabebe E, Anumba, DOC. The vaginal microenvironment: the physiologic role of Lactobacilli. Front Med (Lausanne). 2018 Jun; 5:181. https://doi.org/10.3389/fmed.2018.00181

Biernat-Sudolska M, Rojek-Zakrzewska D, Lauterbach, R. Assessment of various diagnostic methods of ureaplasma respiratory tract infections in newborns. Acta Biochim Pol. 2006 Oct;53(3):609-611. Bıyık İ, Keskin N, Gülcan A, İnce O, Erten Ö, Şişman Hİ. Coinfection of Ureaplasma urealyticum/Mycoplasma hominis in HPV positive women: frequency, risk factors and multidrug resistance. J Clin Obstet Gynecol. 2020;30(3):92-99.

https://doi.org/10.5336/jcog.2020-76299

Daniele M, Ruiz F, Pascual L, Barberis L. Ureaplasma urealyticum and Mycoplasma hominis sensitivity to bacteriocins produced by two lactobacilli strains. Curr Microbiol. 2011 Oct;63(4):360-365. https://doi.org/10.1007/s00284-011-9989-y

Dewan B, Sharma M, Nayak N, Sharma SK. Upper urinary tract stones and Ureaplasma urealyticum. Indian J Med Res. 1997 Jan; 105:15-21.

Geisler WM, Yu S, Venglarik M, Schwebke, JR. Vaginal leucocyte counts in women with bacterial vaginosis: relation to vaginal and cervical infections. Sex Transm Infect. 2004 Oct;80:401-405. https://doi.org/10.1136/sti.2003.009134

Hayflick L. The Mycoplasmatales and the L-phase of bacteria. New York (USA): Meredith Corporation; 1965.

Hearps AC, Tyssen D, Srbinovski D, Bayigga L, Diaz DJD, Aldunate M, Cone RA, Gugasyan R, Anderson DJ, Tachedjian G. Vaginal lactic acid elicits an anti-inflammatory response from human cervicovaginal epithelial cells and inhibits production of pro-inflammatory mediators associated with HIV acquisition. Mucosal Immunol. 2017 Nov;10(6):1480-1490. https://doi.org/10.1038/mi.2017.27 Kundsin RB, Leviton A, Allred EN, Poulin SA. Ureaplasma urealyticum infection of the placenta in pregnancies that ended prematurely. Obstet Gynecol. 1996 Jan;87(1):122-127.

https://doi.org/10.1016/0029-7844(95)00376-2

Linhares IM, Summers PR, Larsen B, Giraldo PC, Witkin SS. Contemporary perspectives on vaginal $\mathrm{pH}$ and lactobacilli. Am J Obstet Gynecol. 2011 Feb;204(2):120.e1-120.e1205.

https://doi.org/10.1016/j.ajog.2010.07.010

Lv P, Zhao F, Xu X, Xu J, Wang Q, Zhao Z. Correlation between common lower genital tract microbes and high-risk human papillomavirus infection. Can J Infect Dis Med Microbiol. 2019 Nov;2019: 9678104. https://doi.org/10.1155/2019/9678104

McDonald MI, Lam MH, Birch DF, D'Arcy AF, Fairley KF, Pavillard ER. Ureaplasma urealyticum in patients with acute symptoms of urinary tract infection. J Urol. 1982 Sep;128(3):517-519. https://doi.org/10.1016/s0022-5347(17)53025-6

Moi H, Reinton N, Randjelovic I, Reponen EJ, Syvertsen L, Moghaddam A. Urethral inflammatory response to ureaplasma is significantly lower than to Mycoplasma genitalium and Chlamydia trachomatis. Int J STD AIDS. 2017 Jul;28(8):773-780.

https://doi.org/10.1177/0956462416666482

Nugent RP, Krohn MA, Hillier SL. Reliability of diagnosing bacterial vaginosis is improved by a standardized method of gram stain interpretation. J Clin Microbiol. 1991 Feb;29(2):297-301.

https://doi.org/10.1128/JCM.29.2.297-301.1991

Núñez-Calonge R, Caballero P, Redondo C, Baquero F, MartínezFerrer M, Meseguer MA. Ureaplasma urealyticum reduces motility and induces membrane alterations in human spermatozoa. Hum Reprod. 1998 Oct;13(10):2756-2761.

https://doi.org/10.1093/humrep/13.10.2756

O'Hanlon DE, Come RA, Moench TR. Vaginal pH measured in vivo: lactobacilli determine $\mathrm{pH}$ and lactic acid concentration. $\mathrm{BMC}$ Microbiol. 2019 Jan;19(1):13.

https://doi.org/10.1186/s12866-019-1388-8 
Okodo M, Kawamura J, Okayama K, Kawai K, Fukui T, Shiina N, Caniz T, Yabusaki H, Fujii M. Cytological features associated with Ureaplasma urealyticum in pap cervical smear. Asian Pac J Cancer Prev. 2017 Aug;18(8):2239-2242.

https://doi.org/10.22034/APJCP.2017.18.8.2239

Razin S. Adherence of pathogenic mycoplasmas to host cells. Biosci Rep. 1999 Oct;19(5):367-372.

https://doi.org/10.1023/a:1020204020545

Razin S. Peculiar properties of mycoplasmas: the smallest self-replicating prokaryotes. FEMS Microbiol Lett. 1992 Dec;100(1-3):423-431. https://doi.org/10.1111/j.1574-6968.1992.tb14072.x

Schwebke JR, Hillier SL, Sobel JD, McGregor JA, Sweet RL. Validity of the vaginal Gram stain for the diagnosis of bacterial vaginosis. Obstet Gynecol. 1996 Oct;88(4 Pt 1):573-576.

https://doi.org/10.1016/0029-7844(96)00233-5

Smith SB, Ravel J. The vaginal microbiota, host defence and reproductive physiology. J Physiol. 2017 Jan;595(2):451-463.

https://doi.org/10.1113/JP271694

Tachedjian G, Aldunate M, Bradshaw CS, Cone RA. The role of lactic acid production by probiotic Lactobacillus species in vaginal health. Res Microbiol. 2017 (Nov-Dec);168(9-10):782-792.

https://doi.org/10.1016/j.resmic.2017.04.001

Taj N, Ul Alam MS, Bajwa Z, Waheed A, Ullah E. Bacterial vaginosis in pregnant women and its diagnosis using Amsel's Clini- cal Criteria and Nugent's Method. Pak J Med Health Sci. 2014; 8: 133-135.

Taylor-Robinson D. Evaluation of the role of Ureaplasma urealyticum in infertility. Pediatr Jnfect Dis. 1986(Nov-Dec);5(6 Suppl): S262-S265.

Virtanen S, Rantsi T, Virtanen A, Kervinen K, Nieminen P, Kalliala I, Salonen A. Vaginal microbiota composition correlates between pap smear microscopy and next generation sequencing and associates to socioeconomic status. Sci Rep. 2019 May;9(1):7750. https://doi.org/10.1038/s41598-019-44157-8

Wagner W, Ciszewski WM, Kania KD. L- and D-lactate enhance DNA repair and modulate the resistance of cervical carcinoma cells to anticancer drugs via histone deacetylase inhibition and hydroxycarboxylic acid receptor 1 activation. Cell Commun Signal. 2015 Jul; 13:36.

https://doi.org/10.1186/s12964-015-0114-x

Witkin SS, Linhares IM. Why do lactobacilli dominate the human vaginal microbiota? BJOG. 2017 Mar;124(4):606-611.

https://doi.org/10.1111/1471-0528.14390

Ye H, Song T, Zeng X, Li L, Hou M, Xi M. Association between genital mycoplasmas infection and human papillomavirus infection, abnormal cervical cytopathology, and cervical cancer: a systematic review and meta-analysis. Arch Gynecol Obstet. 2018 Jun;297(6): 1377-1387. https://doi.org/10.1007/s00404-018-4733-5 